\title{
Inward Foreign Direct Investment and National Innovative Capacity
}

\author{
Meda Andrijauskiene, Daiva Dumciuviene
}

\author{
Kaunas University of Technology \\ K. Donelaicio st. 73, LT-44029, Kaunas, Lithuania \\ E-mail.meda.andrijauskiene@ktu.lt,daiva.dumciuviene@ktu.lt
}

cross $^{\text {ref }}$ http://dx.doi.org/10.5755/j01.ee.30.3.22832

\begin{abstract}
There is a strong debate whether a country's national innovative capacity (NIC) is entirely determined by local effects or it is also influenced by a global network position and international economic activities. The subject of the research is the impact of inward foreign direct investment (IFDI) on NIC. The main aim of this paper is twofold: to focus on IFDI as an input, and engage non-technological innovation as an output in NIC models. In order to reach this aim, a review of scientific literature as well as correlation and regression analyses were used. An investigation of 28 European Union (EU) Member States in the period of 2013-2016 shows that the EU has a great intellectual capacity of human capital which drives both technological and non-technological innovation. Furthermore, it was found out that IFDI and import boost the employment in knowledge-intensive sectors and positively affect the number of trademark and design applications. Nevertheless, despite the efforts to include marketing and organisation innovation as non-technological innovative output, no relationship with the international economic activities (i.e. imports and IFDI) was detected. These findings thus could help to improve national innovation policies and facilitate EU efforts to catch up with the strongest innovators in the World.
\end{abstract}

Keywords: Foreign Direct Investment; Import; Innovation; National Innovative Capacity; the EU.

\section{Introduction}

Though the innovation gap between the EU and the strongest innovators in the world, i.e. United States, Japan, and Canada is being reduced, the innovation performance strongly diverges across the member states with highly uneven progress (European Commission, 2018 a).

By bringing out the different contributions of public research institutes, universities, domestic and foreign enterprises, scholars have been trying to elaborate the drivers and profits of the innovative capacity of regions and countries since 1950's (Schumpeter, 1942; Solow, 1956; Villa, 1990; Furman, Porter, Stern, 2002; Hu, Mathews, 2005, 2008, Franco, Leoncini, 2013; Wu, Ma, Zhuo, 2017).

A wide range of analyses takes research and development (R\&D) expenditures, gross domestic product (GDP) per capita, average years of tertiary schooling, intellectual property protection and specialization in high-tech industry as a proxy for a knowledge stock. This illustrates the problem of a lack of consideration that a national innovative capacity (NIC) is not an exceptionally closed system which requires an adoption of a single economy approach. The latest works reveal that through international diffusion of knowledge IFDI contributes to countries' ability to produce cutting-edge technologies and increase patent applications (Wu et al. 2017; Litsareva, 2017; Filippetti, Frenz, Ietto-Gillies, 2017; Que, Zhang, 2018).

Another strong debate is related to the outputs of the national innovative capacity. Among the most commonly used ones, there are patents, either in the form of an absolute number or rate per million people and patent citation rate (Trajtenberg, 1990; Furman et al., 2002; Boly, Morel, Camargo, 2014). Nevertheless, employment of these indicators gets quite a lot of critique. Firstly, because of the fact that patents are effective to capture innovation in manufacturing but they cannot fully explain innovation in services (Hipp, Grupp, 2005). Secondly, not every innovation is patentable and not every patent is used to create an innovation (Proksch, Haberstroh, Pinkwart, 2017).

To sum up, it can be noticed that, over the recent decades, a scientific attention devoted to innovation capacity has increased, yet at least several areas can be improved with additional empirical research. Having in mind the global challenges and research gaps described above, this paper aims to evaluate the impact of IFDI on the EU Member States' innovative capacity by engaging not only technological but also non-technological innovative output in NIC models. In order to reach this aim, first, the latest scientific literature is reviewed, second, a detailed consideration of data and methods is presented, and third, the findings of the conducted analyses are demonstrated and explained in four different regression models. Lastly, the most relevant results and implications for further research are highlighted.

\section{Literature Review}

\section{National Innovative Capacity and the Importance} of Inward FDI

Science, technology, and innovation has been widely analysed as the crucial determinants of economic growth since the seminal contributions of Schumpeter (1942) and Solow (1956). Almost a half-century later, the concept of innovative capacity was introduced by Villa (1990). Originally, it reflects the changes in technology, invention (note: ideas that are patented) and the competitiveness of economic activities. It also measures the potential for innovation in any geographical area, nation or industry. Naturally, the concept has developed over time. A number of different researchers have argued whether the country's 
national innovative capacity depends only on the investment in research and development and the national intellectual capital or other factors, such as the accumulated technological knowledge, the innovation environment in nation's industrial clusters and the strength of linkage between private and public sector are equally important $(\mathrm{Wu}$ et al., 2017). Authors investigating at micro level described innovative capacity as company's ability to obtain technology, i.e. by licensing and/or imitating foreign companies and/or conducting formal research and pioneering their own new products and processes (Halkos, Skouloudis, 2018) and those who examined at macro level characterised the innovative capacity as a country's potential (as both an economic and political entity) to produce a long term stream of commercially relevant innovations (Liu, White, 2001; Furman et al., 2002; Furman, Hayes, 2004; Hu, Mathews, 2005; 2008).

In 2002, Furman et al. proposed the determinants of national innovative capacity, claiming it is based on three distinct areas: quality of the common innovation infrastructure, quality of the cluster-specific innovation environment, and quality of linkages:

- Common innovation infrastructure includes GDP per capita, the amount of scientific and technical skills devoted to the production of new technologies, R\&D personnel, R\&D expenditure, national investments and policy choices, expenditures on higher education, intellectual property protection and openness to international competition.

- Cluster-specific innovation environment is explained by private R\&D funding.

- Quality of linkages between common innovation infrastructure and industrial clusters is revealed by university $R \& D$ performance.

According to the authors, the intensity of linkages influences the extent to which the potential for innovation evoked by the common innovation infrastructure is translated into specific innovative outputs in a nation's industrial clusters.

In 2005, $\mathrm{Hu}$ and Mathews were analysing the contributions to NIC by six sectors: public research institutes, universities, state-owned enterprises, private enterprises, foreign ventures, and individuals. Scholars noticed that 4 variables, i.e. patent stocks, levels of $R \& D$ manpower, private R\&D expenditure and specialization in high-tech industry along with public $R \& D$ funding play a different role in the process of building national innovation capacity when comparing the latecomer and the more advanced countries.

In 2008, Hu and Mathews additionally supplemented the set of determinants proposed by Furman, et al., 2002. They added a variable of population and the strength of antitrust law of regime for the protection of Intellectual Property Rights in common innovation infrastructure, specialization in technological sectors in cluster-specific innovation environment and the venture capital availability in linkages between innovative infrastructure and industrial clusters.

The results of research performed by Crescenzi, Rodriguez-Pose and Storper (2007), Huang et al. (2010), Franco, Leoncini, (2013), Proksch, Haberstroh, Pinkwart (2017) show that national innovative capacity is not exclusively determined by local effects, e.g. R\&D resource for technology development but is also influenced by global network position and international cooperation. According to Crescenzi, Rodriguez-Pose and Storper (2007), a certain economic geography in which innovation takes place is dependent on financial flows of businesses and workers and the magnitude to which these generate or follow innovation. Links between IFDI and innovation are investigated in some other scientific works. Bertschek (1995), for example, finds that imports and IFDI have a considerable positive impact on product and process innovation and this is mainly influenced by a competition with foreign firms which encourages innovation in domestic enterprises. At the largescale degree, Borensztein, De Gregorio, Lee (1998) confirm a positive relationship between iFDI and technology diffusion. Nevertheless, FDI resulted to be more productive than domestic investment only when the reporting country has a minimum threshold of human capital. The research of Filippetti et al. (2017) extended these findings with the conclusion that countries can benefit from IFDI yet these advantages do not apply to the countries with lower levels of absorptive capacity (AC). Hence, before putting efforts on receiving foreign investment, nations seeking to increase their innovation performance should firstly invest in domestic elements of absorptive capacity such as relevant human resources, physical infrastructure and R\&D.

$\mathrm{Wu}$ et al. (2017), on the contrary, remark that the international economic activities (i.e. high-tech export and IFDI) contribute to developing countries' ability to produce cutting-edge technologies, but this effect does not extend for leading innovator countries. As the authors state, the emerging countries achieve economic growth and efficiency through the embodied technology of their more innovative partners.

The latest studies prove that a critical assessment of the traditional approach of a closed-system analysis is essential. However, though scholars demonstrate the relationship between iFDI and innovation capacity of the host country, the results are quite diverse because of the different inputs and methods used. Therefore, a further investigation of economic integration variables as inputs of NIC models is necessary.

\section{The Conceptual Frameworks of National Innovative Capacity}

Methods for measuring national innovative capacity vary. The simplest and most widespread way in empirical practice is using, measuring and predicting simple index numbers. Using these methods researchers often pick out one of a large amount of indicators or a set of them, which are considered to be the most dominant to describe the essence of innovation capacity (Kasa, 2015). As for example, Makkonen, Inkinen (2013) use Granger causality tests. Other empirical designs are based on correlation and regression models (e.g. Furman et al., 2002; Faber, Hesen, 2004; Huang et al., 2010; Filippetti, et al., 2017; Franco, Leoncini, 2013; Wu et al., 2017; Halkos, Skouloudis, 2018), autocorrelation models (e.g, Huang, Shih, Wu, 2010), OLS regression models (e.g. Zang, Xiong, Lao, Gao). Scholars also tend to use multidimensional regression models, such as exploratory and confirmatory factor analysis (e.g. Lee, Pose, 2013; Zhao, Wang, Zhou, 2010; Filippetti et al., 
2017). Further alternatives are stochastic frontier analysis (SFA), as for example Franco, Leoncini, (2013), time multidimension dynamic comprehensive evaluation (e.g. $\mathrm{Yu}$, Jianzhong, 2011), neuro-fuzzy models (e.g. Kasa, 2015) and qualitative comparative analysis, based on Boolean algebra and fuzzy-set theory (e.g. Proksch et al., 2017).

There is a substantial agreement that national innovative capacity greatly depends on the expenditures which are directly related to innovative processes. The "most popular" input indicators for NIC (see Table 1) are R\&D expenditures, private investment on education\&training and public expenditures on higher education (e.g. Hu, Mathews, 2008; Huang et al., 2010; Kasa, 2015). Intellectual property protection, specialization in high - tech or other country specific innovative industry, the efficiency of clusters and networks are also commonly used indicators (e.g. Sandu, Ciocanel, 2014; Zeng, 2017, European Commission, 2018 a). The latest studies (Gong, Keller, 2003; Huang et al.; Franco, Leoncini, 2013; Wu et al., 2017, Halkos, Skoloudis, 2018) tend to additionally involve the indicators which depict the economic openness of a region, i.e. exports of goods and services/high - tech related export/inward and outward FDI. Control variables usually consist of GDP per capita, population growth rate, urbanization and employment share (e.g. Hu, Mathews, 2008, Lee, Pose, 2013; Proksch et al., 2017).

Table 1

Frequently used Indicators for the Measurement of Input and Output of National Innovative Capacity

\begin{tabular}{|c|c|}
\hline NIC input indicators & NIC output indicators \\
\hline $\begin{array}{l}\text { Expenditures: R\&D expenditures; private investment on education\&training; public } \\
\text { expenditures on higher education. }\end{array}$ & $\begin{array}{l}\text { Patents: absolute number of patents; patent rate per million } \\
\text { people; patent citation rate. }\end{array}$ \\
\hline Level of property right protection: intellectual property protection. & High-tech share of GDP. \\
\hline $\begin{array}{l}\text { Specialization: specialization in high-tech or other country - specific innovative } \\
\text { industry. }\end{array}$ & Copyrights, trademarks, design applications. \\
\hline $\begin{array}{l}\text { Human resources: new doctorate graduates, a population with tertiary education, } \\
\text { total R\&D personnel. }\end{array}$ & $\begin{array}{l}\text { Employment: employment in knowledge-intensive activities; } \\
\text { employment in fast-growing enterprises in innovative sectors. }\end{array}$ \\
\hline $\begin{array}{l}\text { Economic openness: export and import, inward and outward foreign direct } \\
\text { investment. }\end{array}$ & $\begin{array}{l}\text { Sales: share of innovative sales; medium and high technology } \\
\text { product exports; knowledge-intensive services exports. }\end{array}$ \\
\hline $\begin{array}{l}\text { The efficiency of clusters and networks: innovative SMEs collaborating with others; } \\
\text { public-private co-publications; private co-funding of public R\&D expenditures. }\end{array}$ & \multirow[t]{2}{*}{$\begin{array}{l}\text { Non-technological innovation: SMEs introducing marketing or } \\
\text { organisational innovations. }\end{array}$} \\
\hline $\begin{array}{l}\text { Control variables: GDP per capita; urbanisation rate; population density; } \\
\text { employment share; gender equality, regime durability, and political stability; } \\
\text { political imprisonment and cultural diversity; average years of tertiary schooling. }\end{array}$ & \\
\hline \multicolumn{2}{|c|}{ Publications: number of scientific and technical journal articles (used as both input and output). } \\
\hline
\end{tabular}

Authors 'own elaboration based on Trajtenberg, 1990; Villa, 1990; Furman, et al., 2002; Gong, Keller, 2003; Hu, Mathews, 2005; 2008; Huang et al., 2010; Sandu, Ciocanel, 2014; Boly et al., 2014; Kasa, 2015; Proksch et al., 2017; Lee, Rodriguez-Pose, 2013; Franco, Leoncini, 2013; Zeng, 2017; Wu et al., 2017; Zang et al., 2018; European Commission, 2018 a; Halkos, Skoloudis, 2018

Though innovation can "have various forms (product, market, process or social innovation), derived from diverse sources (closed vis-à-vis open innovation) and pertain to different scopes of change, i.e. disruptive, incremental or reapplied innovation" (Halkos, Skouloudis, 2018, p. 292), a lot of researchers use a popular approach to measure the output of innovative capacity by using patents or patent citations rate as a proxy (Trajtenberg, 1990; Furman et al., 2002), arguing that:

- Patents are the only observable manifestation of inventive activity with a well-grounded claim for universality (Trajtenberg, 1990);

- "Patents are intermediary results of the new product development process and are consequently indicative of the invention's activity and of research efforts" (Boly et al., 2014, p. 609);

Nevertheless, despite the frequency of usage of patents and patent citation rate as the output of NIC, it gets a considerable amount of critique:

- Not every patent is used to create an innovation (Proksch et al., 2017);

- Modern technologies are not always distinctly proprietary in nature or granted with the patent right $(\mathrm{Wu}$ et al., 2017);

- "The use of traditional tools creates an innovation gap, so that actual innovation is higher than measured innovation, and the more economies are service-based, the wider the innovation gap" (De Liso, Vergori, 2017).
As innovative capacity primarily depends upon the investments and policy choices of both institutions and the private sector, measuring NIC output includes not only patents or citation rate but also other elements of intellectual property, e.g. copyrights, trademarks and design applications (Huang et al., 2010). According to the European Commission (2018 a), by identifying the origin of goods and services, trademarks are very important innovation indicator for the service sector. In addition to the mentioned indicators, international innovation ranks (e.g. European Innovation Scoreboard (EIS)) evaluates the number of scientific publications, employment in knowledge-intensive activities and innovative sectors. Besides that, EIS at least partially solves the problem of a lack of attention devoted to non-technological innovation and includes the indicator "SMEs introducing marketing or organisational innovations". The particular indicator was used in the later analysis as a proxy for non-technological innovation.

It can be concluded that a wide range of indicators is used when analysing the drivers and gains of national innovative capacity. Starting with the origins - R\&D expenditures and patents, scholars have supplemented the models with a more complex qualitative and quantitative indicators of knowledge stock, intangible resources, networks and even policy - makers' techniques for successful international economic activities. 


\section{Methodology}

Seeking to enrich the research on national innovative capacity, the most recent available data (from 2013 to 2016) was collected for $28 \mathrm{EU}$ Member States (note: United
Kingdom is scheduled to leave the Union on October 31 2019). Two sources that meet all statistical requirements were used in order to construct the evidence for 11 variables: Eurostat and EIS 2018 database (see Table 2).

Definitions of Variables

\begin{tabular}{|l|l|l|l|}
\hline \multicolumn{2}{|c|}{ NIC INPUTS } & \multicolumn{2}{c|}{ NIC OUTPUTS } \\
\hline EDU_EXP & $\begin{array}{l}\text { Government expenditure on education, \% } \\
\text { of GDP }\end{array}$ & EMPLOYMENT & $\begin{array}{l}\text { Employment in knowledge-intensive activities, \% of } \\
\text { total employment }\end{array}$ \\
\hline PUBLIC_R\&D & $\begin{array}{l}\text { R\&D expenditure in the public sector, \% } \\
\text { of GDP }\end{array}$ & NON_TECH_INN & $\begin{array}{l}\text { SMEs introducing marketing or organisation } \\
\text { innovations, \% of SMEs }\end{array}$ \\
\hline PRIVATE_R\&D & $\begin{array}{l}\text { R\&D expenditure in the business sector, } \\
\% \text { of GDP }\end{array}$ & PATENT_GDP & $\begin{array}{l}\text { PCT patent applications per billion GDP, in } \\
\text { purchasing power standard (PPS)) }\end{array}$ \\
\cline { 1 - 2 } TER_EDUCATION & $\begin{array}{l}\text { Percentage of population having tertiary } \\
\text { education (levels 5-8) }\end{array}$ & TRADEMARK_GDP & Trademark applications per billion GDP, in PPS \\
\cline { 1 - 2 } i_FDI_GDP & $\begin{array}{l}\text { Direct investment in the reporting } \\
\text { economy (DIRE), \% of GDP }\end{array}$ & DESIGN_GDP & Design applications per billion GDP, in PPS \\
\cline { 1 - 3 } IMPORT & Imports of goods and services, \% of GDP &
\end{tabular}

Source: Eurostat database (Eurostat, 2018; https://lec.europa.eu/eurostat/data/database); EIS 2018 database (European Commission, 2018 b; https://ec.europa.eu/docsroom/documents/30282)

As presented in Table 2, on the left, six variables act as independent ones in the latter correlation and regression analyses (government expenditure on education (EDU_EXP), R\&D expenditure in the public sector (PUBLIC_R\&D), R\&D expenditure in the business sector (PRIVATE_R\&D), percentage of population having tertiary education (TER_EDUCATION), direct investment in the reporting economy (i_FDI_GDP) and imports of goods and services (IMPORT)).

On the right, five dependent variables are hereby also used in the above mentioned empirical investigation, (employment in knowledge-intensive activities (EMPLOYMENT), SMEs introducing marketing or organisation innovations (NON_TECH_INN), patent applications (PATENT_GDP), trademark applications (TRADEMARK_GDP) and design applications (DESIGN_GDP)), see Table 4 - Table 12 .
Note: due to the fact that the correlation analysis showed no significant relationship with the international economic activities (i.e. imports and IFDI), the variable NON_TECH_INN was excluded from the regression modeling).

\section{Empirical Findings}

Table 3 illustrates the descriptive statistics. On average, during 2013-2016, Member States allocated 5,12 $\%$ of GDP to education, public R\&D expenditures made up $0,61 \%$ and private R\&D expenditures $-0,96 \%$ of GDP. Almost one-third of Union's inhabitants have a tertiary education and $33 \%$ of SMEs already introduced marketing and organisational innovations during the analysed period of time. This indicates that the EU has a great potential of intellectual labour for both technological and nontechnological innovation.

Table 3

Descriptive Statistics ( $=112)$

\begin{tabular}{|c|c|c|c|c|}
\hline & Minimum & Maximum & Mean & Std. Deviation \\
\hline EDU_EXP & 2,80 & 7,10 & 5,12 & ,95775 \\
\hline PUBLIC_R_D & ,20 & 1,10 & ,61 &, 24304 \\
\hline PRIVATE_R_D &, 10 & 2,30 & ,96 & ,66793 \\
\hline TER_EDUCATION & 13,80 & 39,60 & 27,00 & 7,06360 \\
\hline IMPORTS & 26,40 & 187,50 & 62,42 & 33,30973 \\
\hline i_FDI_GDP & 9,90 & 851,00 & 96,26 & 148,40001 \\
\hline EMPLOYMENT & 6,50 & 22,90 & 13,78 & 3,71729 \\
\hline NON_TECH_INN & 8,80 & 54,30 & 32,76 & 11,94500 \\
\hline PATENT_GDP &, 30 & 9,10 & 2,58 & 2,22989 \\
\hline TRADEMARK_GDP & 2,10 & 44,00 & 10,69 & 9,84892 \\
\hline DESIGN_GDP &, 30 & 22,30 & 4,56 & 4,19470 \\
\hline
\end{tabular}

The data in Table 3 also indicates that there is a considerable lack of convergence in imports of goods and services, the amount of inward foreign direct investment and intellectual assets. The possible reasons of differences in NIC outputs are revealed by correlation analysis and multiple regression models (see models 1 to 4 ).
Correlation analysis (Table 4) discloses that employment in knowledge-intensive sectors has a positive relationship with private $\mathrm{R} \& \mathrm{D}$ expenditures $(, 409 ; \mathrm{p}=0,000)$, imports of goods and services $(, 429 ; \mathrm{p}=0,000)$ and IFDI $(, 384 ; \mathrm{p}=0,000)$. Furthermore, the correlation is strong between this variable and the amount of population with 
tertiary education $(, 600 ; \mathrm{p}=0,000)$. Talking about interrelations between national innovative capacity outputs (not included in the table), it is worth to note that employment in knowledge-intensive sectors also had a positive correlation with patent variable $(, 366, \mathrm{p}=0,000)$, trademark variable $(, 582, \mathrm{p}=0,000)$ and design variable $(, 453, \mathrm{p}=0,000)$.

Another analysed output of NIC is non-technological innovation (i.e. SMEs introducing marketing or organisation innovations, $\%$ of SMEs). It was found out that there is no relationship between non-technological innovation results and international economic activities (i.e. imports and iFDI), hence it is not included in a further analysis, but it is worth to note that it correlates moderately with $R \& D$ investments $(, 400 ; p=0,000 ;, 490 ; p=0,000)$ and population with tertiary education (,390; $p=0,000)$.
As Table 4 demonstrates, patent applications might (more info in regression models) strongly depend on public and private $R \& D$ expenditures (respectively: , 750; $p=0,000$; ,911; $\mathrm{p}=0,000)$. There is also a moderate positive relationship with expenditures on education and a weak negative relationship with the variable "Imports" (-,285; $\mathrm{p}=0,002$ ).

Continuing with other intellectual assets, trademarks might strongly depend on international economic inflows (respectively on Import: ,653; $\mathrm{p}=0,000$ and iFDI: ,556; $\mathrm{p}=0,000)$. There is also a weak correlation observed with expenditures on education $(, 262 ; \mathrm{p}=0,000)$ and population with tertiary education $(, 255 ; \mathrm{p}=0,000)$.

Correlation Analysis

\begin{tabular}{|c|c|c|c|c|c|c|c|}
\hline & & EDU_EXP & $\begin{array}{c}\text { PUBLIC } \\
\text { R\&D }\end{array}$ & $\begin{array}{c}\text { PRIVATE_R } \\
\text { \&D }\end{array}$ & $\begin{array}{l}\text { TERTIARY } \\
\text { EDUCATION }\end{array}$ & IMPORT & i_FDI_GDP \\
\hline \multirow{2}{*}{ EMPLOYMENT } & Pearson Corr. &, $293^{* *}$ &, $224^{*}$ &, $409^{* *}$ &, $600^{* *}$ & $429^{* *}$ &, $384^{* *}$ \\
\hline & Sig. (2-tailed) &, 002 &, 017 & ,000 &, 000 &, 000 &, 000 \\
\hline \multirow{2}{*}{ NON_TECH_INN } & Pearson Corr. & ,161 &, $400^{* * *}$ & ,490** & ,390** & , 135 & ,045 \\
\hline & Sig. (2-tailed) &, 090 &, 000 &, 000 &, 000 & , 156 & ,651 \\
\hline \multirow{2}{*}{ PATENT_GDP } & Pearson Corr. &, $395^{* *}$ &, $750^{* *}$ &, $911^{\text {** }}$ &, $273^{* *}$ &,$- 285^{* *}$ &,- 029 \\
\hline & Sig. (2-tailed) &, 000 &, 000 &, 000 &, 004 &, 002 &, 770 \\
\hline \multirow{2}{*}{ TRADEMARK_GDP } & Pearson Corr. & $262^{* *}$ &,- 142 &,- 114 & $255^{* *}$ & $653^{\text {** }}$ & $556^{\text {** }}$ \\
\hline & Sig. (2-tailed) &, 005 &, 135 &, 233 & ,007 &, 000 & ,000 \\
\hline \multirow{2}{*}{ DESIGN_GDP } & Pearson Corr. & ,137 &, 058 &, 128 &,- 006 &, $521^{\text {** }}$ &,- 126 \\
\hline & Sig. (2-tailed) & ,149 &, 545 &, 177 & ,951 &, 000 & ,207 \\
\hline
\end{tabular}

Finally, the correlation analysis revealed that the dependent variable "Design applications" is related with only one independent variable, i.e. "Import" (,521; $\mathrm{p}=0,000)$.

The authors of this paper emphasize that the correlation method can only tell how the values of variables co-vary. Hence, in order to make a stronger claim, regression analysis was applied. 4 unique models were created in respect with different national innovative capacity outputs and their relationship with international economic inflows, i.e. imports (as a control) and inward foreign direct investment (key).

\section{Model 1. NIC Output: Employment in Knowledge- Intensive Sectors}

The tables below (see Table 5, Table 6) present the key statistics of the final version of a multiple linear regression model 1 (with the omitted insignificant variables). It can be noted, that the predictors iFDI, Private R\&D, Imports and Population with tertiary education can explain the fluctuations of the dependent variable "Employment in knowledge-intensive activities" by $64 \%$.

Model 1 Summary

\begin{tabular}{|c|c|c|c|c|}
\hline Model & R & R Square & Adjusted R Square & Std. Error of the Estimate \\
\hline 1 &, $807^{\mathrm{a}}$ &, 651 &, 636 & 2,24202 \\
\hline
\end{tabular}

a. Predictors: (Constant), i_FDI_GDP, PRIVATE_R_D, IMPORTS, TER_EDUCATION

b. Dependent Variable: EMPLOYMENT

Final Results of Model 1 Statistical Significance Test

\begin{tabular}{|c|c|c|c|c|c|c|c|c|}
\hline & & \multicolumn{2}{|c|}{$\begin{array}{l}\text { Unstandardized Coefficients } \\
\text { B } \quad \text { Std. Error }\end{array}$} & \multirow[t]{2}{*}{$\begin{array}{c}\text { Standardized Coefficients } \\
\text { Beta }\end{array}$} & \multirow{2}{*}{$\begin{array}{c}\mathrm{t} \\
2,904\end{array}$} & \multirow{2}{*}{$\begin{array}{l}\text { Sig. } \\
, 005\end{array}$} & \multicolumn{2}{|c|}{$\begin{array}{l}\text { Collinearity Statistics } \\
\text { Tolerance VIF }\end{array}$} \\
\hline \multirow{5}{*}{1} & (Constant) & 2,816 & ,970 & & & & & \\
\hline & PRIVATE_R_D & 2,333 & ,365 & ,419 & 6,396 &, 000 & ,839 & 1,193 \\
\hline & TER_EDUCATION &, 199 &, 035 & ,379 & 5,691 & ,000 & ,814 & 1,228 \\
\hline & IMPORTS & ,046 & ,007 & 409 & 6,297 & ,000 & ,852 & 1,174 \\
\hline & i_FDI_GDP &, 005 &, 002 & ,198 & 2,983 &, 004 &, 816 & 1,225 \\
\hline
\end{tabular}


There is no multicollinearity (see Table 6) between the independent variables $(1 \leq \mathrm{VIF} \leq 10)$, thus the final proposed regression model 1 equation:

$$
\begin{aligned}
& Y_{\text {employment }}=2,816+2,333_{\text {private } R \& D}+0,199 \text { tertiary } \\
& \text { education }+0,046_{\text {imports }}+0,005_{\text {iFDI }}
\end{aligned}
$$

Accordingly, it can be concluded that an employment in knowledge-intensive sectors is encouraged when 1) ventures invest in $R \& D, 2$ ) citizens are motivated to acquire tertiary education, 3) market is open 4) conditions for foreign direct investment are favourable.

\section{Model 2. NIC Output: PCT Patent Applications per Billion GDP}

The tables below (see Table 7, Table 8) present the key statistics of the final version of multiple linear regression model 2 (with the omitted insignificant variables). The predictors Imports, Public R\&D, and Private R\&D can explain the fluctuations of the dependent variable "PCT patent applications per billion GDP" by $85 \%$.

Model 2 Summary

\begin{tabular}{|c|c|c|c|c|}
\hline Model & R & R Square & Adjusted R Square & Std. Error of the Estimate \\
\hline 2 &, $924^{\mathrm{a}}$ &, 853 &, 849 &, 86534 \\
\hline
\end{tabular}

a. Predictors: (Constant), IMPORTS, PUBLIC_R_D, PRIVATE_R_D

b. Dependent Variable: PATENT_GDP

Table 8

Final Results of Model 2 Statistical Significance Test

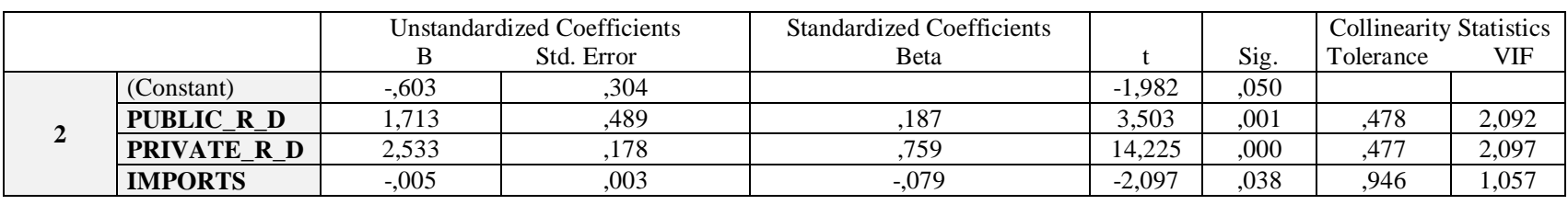

There is no multicollinearity (see Table 8 ) between the independent variables $(1 \leq \mathrm{VIF} \leq 10)$, hence the final proposed regression model 2 equation:

\section{YPCT patent applications per billion GDP $=2,533$ Private R\&D + 1,713Public R\&D - 0,005Imports - 0,603}

Thereupon, the result shows that the amount of Patent applications strongly depends on Public and Private investment on $R \& D$ and is slightly negatively influenced by the Imports of goods and services. This is an unexpected outcome because logically, import (as for example of hightech products) should provide access to new technologies and help to develop innovative capabilities of a country. Though international trade variable was used just for control, the future research should involve this aspect as an important one and it might be useful to differentiate import by type of goods and services.

\section{Model 3. NIC Ooutput: Trademark Applications per Billion GDP}

The tables below (see Table 9, Table 10) presents the key statistics of the final version of multiple linear regression model 3 (with the omitted insignificant variables). The predictors Inward foreign direct investments, Imports, and Expenditures for education can explain the fluctuations of the dependent variable "Trademark applications per billion GDP" by $58 \%$.

Model 3 Summary

\begin{tabular}{|c|rr|r|r|r|}
\hline Model & R & R Square & Adjusted R Square & Std. Error of the Estimate \\
\hline 3 & &, $770^{\mathrm{a}}$ & &, 593 & 2,73877 \\
\hline
\end{tabular}

a. Predictors: (Constant), i_FDI_GDP, EDU_EXP, IMPORTS

b. Dependent Variable: TRADEMARK_GDP

Table 10

\begin{tabular}{|c|c|c|c|c|c|c|c|c|}
\hline & \multirow{2}{*}{ Model } & \multicolumn{2}{|c|}{ Unstandardized Coefficients } & \multirow{2}{*}{$\begin{array}{c}\begin{array}{c}\text { Standardized } \\
\text { Coefficients }\end{array} \\
\text { Beta }\end{array}$} & \multirow{2}{*}{$\mathrm{t}$} & \multirow{2}{*}{ Sig. } & \multicolumn{2}{|c|}{ Collinearity Statistics } \\
\hline & & B & Std. Error & & & & Tolerance & VIF \\
\hline \multirow{4}{*}{3} & (Constant) & $-11,317$ & 2,618 & & $-3,128$ & ,002 & & \\
\hline & EDU_EXP & 1,954 & 668 & ,190 & 2,926 & ,004 & ,984 & 1,016 \\
\hline & IMPORTS & 155 & ,020 &, 525 & 7,701 & ,000 & 893 & 1,120 \\
\hline & i_FDI_GDP & ,024 & ,005 & ,361 & 5,254 & ,000 & 882 & 1,134 \\
\hline
\end{tabular}

Final Results of Model 3 Statistical Significance Test 
There is no multicollinearity (see Table 10) between the independent variables $(1 \leq \mathrm{VIF} \leq 10)$, therefore, the final proposed regression model 3 equation:

$$
\begin{aligned}
& Y_{\text {Trademark applications per billion GDP }=1,954 \text { Expenditures for }}
\end{aligned}
$$

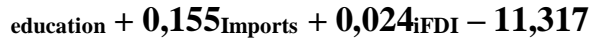

The model reveals that the number of Trademark applications can be increased with greater expenditures on education, import-promotion policies and friendly environment for foreign capital inflows in the host country.

\section{Model 4. NIC output: Design applications per billion GDP}

The tables below (see Table 11, Table 12) present the key statistics of the final version of a simple linear regression model (with the omitted insignificant variables). The predictor Import can explain the fluctuations of the dependent variable "Design applications per billion GDP" by $27 \%$. The low reliability of the model is also indicated by std. error of the estimate which is equal to 3,59731. This means that there is a space for more research on possible independent variables which causes the amount of design applications.

Table 11

Model 4 Summary

\begin{tabular}{|c|c|c|c|c|}
\hline Model & R & R Square & Adjusted R Square & Std. Error of the Estimate \\
\hline 4 &, $521 \mathrm{a}$ &, 271 &, 265 & 3,59731 \\
\hline
\end{tabular}

a. Predictors: (Constant), IMPORTS

b. Dependent Variable: DESIGN_GDP

Table 12

Final Results of Model 4 Statistical Significance Test

\begin{tabular}{|c|c|c|c|c|c|c|c|c|}
\hline & \multirow{2}{*}{ Model } & \multicolumn{2}{|c|}{ Unstandardized Coefficients } & Standardized Coefficients & \multirow{2}{*}{$\mathrm{t}$} & \multirow{2}{*}{ Sig. } & \multicolumn{2}{|c|}{ Collinearity Statistics } \\
\hline & & $\mathrm{B}$ & Std. Error & Beta & & & Tolerance & VIF \\
\hline \multirow{2}{*}{4} & (Constant) & 469 &, 725 & & 647 &, 519 & & \\
\hline & IMPORTS & ,066 & ,010 &, 521 & 6,397 &, 000 & 1,000 & 1,000 \\
\hline
\end{tabular}

The final proposed regression model 4 equation:

$Y_{\text {Design applications per billion GDP }}=\mathbf{0 , 4 6 9}+\mathbf{0 , 0 6 6}$ Imports

Though the model is not the most accurate (the vast majority of independent variables could not explain the fluctuations of an independent variable), it is important to note that the correlation analysis performed above (see Table 4) has shown that there is a positive moderate correlation $(, 521 ; p=0,000)$ between the variables of Imports of goods and services and Design applications. This means that the amount of Design applications can be increased by effective import-promotion policies.

\section{Discussion}

It was argued and, with the help of correlation and regression analysis, proved that inward foreign direct investment supports a country's national innovative capacity by encouraging the employment in knowledgeintensive sectors and having a positive effect on trademark and design applications. These results are in line with Blind, Edler, Frietsch and Schmoch (2006), Ghazal, Zulkhibri (2015) and Zhang (2017) who have proven that trademark and design applications are positively related to the FDI inflows to the economy.

Though the chosen sample of an economically developed European Union in 2013-2016 did not reveal any significant relationship between IFDI and patents, a number of scholars claim that this relationship is significant and positive in the emerging countries (e.g. China, Brazil or Israel). By attracting more FDI and facilitating international technology diffusion through forthright learning about foreign advanced intermediate products or methods, they are rapidly catching up with the leading innovative countries (e.g. Gong, Keller, 2003; Furman, Hayes, 2004; Wu et al., 2017; Proksch et al., 2017).

China remains the pre-eminent recipient of IFDI among developing countries and is catching up the EU at three times the Union's innovation performance growth rate. This illustrates how important pro-inward FDI policy can be. Gotz (2016) analysed the policies towards the outward and IFDI in the European Union and classified the member states in terms of their approach. Four policy models were distinguished: 1) an open model with "a double positive strategy", where both types of FDI are seen as making positive contributions to the economy; 2) a closed model with "a double negative strategy", where both outbound and inbound investment is associated with certain losses to the national economy; 3) competitive model with "a positive OUT, negative IN strategy" and 4) a capital model with "a positive IN, negative OUT strategy. Hence, if China's example of inward FDI policy could be considered as worth to follow, an open model where the policy is pursued with the aim of increasing the inflow of new foreign investors and fostering the internationalisation by domestic firms could be applied by modest and moderate innovators in the EU.

\section{Conclusions}

Though a lot of researches interpreted national innovative capacity as a closed system which requires adoption of a single economy approach, the latest works show that through international diffusion of knowledge, inward foreign direct investment and other elements of international economic activities significantly contribute to 
country's ability to innovate. However, not a lot of studies include the features of economic openness, i.e. export/import/foreign direct investment and limit themselves with exclusively domestic indicators for NIC (such as public and private $\mathrm{R} \& \mathrm{D}$ expenditures, the share of human resources with intellectual potential (e.g. population with tertiary education) and the level of intellectual property protection)).

Among the most commonly used NIC outputs, there are patents and patent citation rate. Nevertheless, it gets a considerable amount of critique, mainly because of the fact that not every innovation is patentable and not every patent is used to create an innovation. Consequently, despite its' importance, there is a lack of studies which take the variables of non-technological innovation into account.

Seeking to enrich the research on national innovative capacity, the regression models were supplemented with international economic activities, i.e. IFDI (key) and imports (control) and non-technological innovative output, i.e. SME's introducing marketing and organisational innovations.

An investigation of 28 EU Member States in the year of 2013-2016 demonstrates that the EU has a great intellectual capacity of human capital which drives both technological and non-technological innovation.

The analysis has shown that the employment in knowledge-intensive sectors can be boosted via private investment in $\mathrm{R} \& \mathrm{D}$, purposeful use of the potential of highly educated people and international transmission of knowledge through inward foreign direct investment and imports of goods and services.

Despite the efforts to include the variable of nontechnological innovation, no relationship between international economic activities (i.e. imports and IFDI) and non-technological innovation results was found. Nevertheless, this outcome may be influenced by the lack of a particular data (see Limitations and future research).

Continuing with the intellectual property and outputs of technological innovation, the analysis has shown that the number of patent applications can be increased by shifting more private and public funds to R\&D investment. Quite unexpectedly, regression analysis revealed imports' negative effect on patent applications. On the other hand, import of goods and services has a relevant positive effect on design applications, and, together with IFDI, act as important elements affecting the amount of countries' trademark applications.

It is recommended, however, that the policy - makers of less innovative EU member states should first increase the efficiency of processes that are already performed within their country and promote the key elements of NIC, such as investing in the development of intellectual capital, building the efficient partnership networks, ensuring intellectual property rights, etc.. Having the sufficient basis, FDI can latter act as a successful addition to the existing status, bring new production techniques and management know-how which, in the end, make the local companies more productive, profitable and competitive.

\section{Limitations and Future Research}

Despite the importance of the non-technological dimension of innovation, the formal technological and economic aspects have been taken into account in a far greater number of analyses (Pereira \& Romero, 2013). Seeking to fill in this research gap, the variable "SMEs introducing marketing and organisational innovations" was employed. However, the authors of this paper faced with a problem that the last Community Innovation Survey (which is used as a source for the mentioned variable) was performed back in 2014, and filling up the data from 2014 into 2015 and 2016 could lead to the fact that a correlation analysis did not show any relation between international economic inflows and non-technological innovation. In addition to this, differentiating imports and exports by type of goods and services might also bring new beneficial results.

Finally, the aspect of international cooperation could also be involved by taking such variables as European and International co-patenting or foreign ownership of domestic inventions in patent applications as innovative outputs of NIC.

\section{References}

Bertschek, I. (1995). Product and process innovation as a response to increasing imports and foreign direct investment, Journal of Industrial Economics, 43(4), 341-57. https://doi.org/10.2307/2950548

Blind, K. , Edler, J. , Frietsch, R. and Schmoch, U. (2006), "Motives to patent: empirical evidence from Germany", Research Policy, 35(5), pp. 655-672. https://doi.org/10.1016/j.respol.2006.03.002

Boly, V., Morel, L., \& Camargo, M. (2014). Evaluating innovative processes in french firms: Methodological proposition for firm innovation capacity evaluation. Research Policy, 43(3), 608-622. https://doi.org/10.1016/j.respol. 2013.09.005

Borensztein, E., De Gregorio, J. \& Lee, J.-W. (1998). How does foreign direct investment affect economic growth?, Journal of International Economics, 45(1), 115-35. https://doi.org/10.1016/S0022-1996(97)00033-0

Crescenzi, R., Rodri'guez-Pose, A. \& Storper, M. (2007) The territorial dynamics of innovation: a Europe-United States comparative analysis. Journal of Economic Geography, 7, 673-709. https://doi.org/10.1093/jeg/lbm030

De Liso, N., \& Vergori, A. S. (2017). The Different Approaches to the Study of Innovation in Services in Europe and the USA. Metroeconomica, 68(1), 121-146. https://doi.org/10.1111/meca.12129 
European Commission, (2018 a). European Innovation Scoreboard 2018 Main report, available at: https://ec.europa.eu/docsroom/documents/30281 [accessed 10/09/2018]

European Commission, (2018 b). EIS 2018 database, available at: https://ec.europa.eu/docsroom/documents/30282 [accessed 10/09/2018]

Eurostat (2018), available at: https://ec.europa.eu/eurostat/data/database [accessed 19/09/2018]

Faber, J., Hesen, A.B., 2004. Innovation capabilities of European nations. Research Policy 33 (2), $193-207$. https://doi.org/10.1016/S0048-7333(03)00122-7

Filippetti, A., Frenz, M., \& Ietto-Gillies, G. (2017). The impact of internationalization on innovation at countries' level: the role of absorptive capacity. Cambridge Journal of Economics, 41(2), 413-439. https://doi.org/10.1093/cje/bew032

Franco, C., \& Leoncini, R. (2013). Measuring China's innovative capacity: a stochastic frontier exercise. Economics of Innovation and New Technology, 22(2), 199-217. https://doi.org/10.1080/10438599.2012.744174

Furman, J. L., \& Hayes, R. (2004). Catching up or standing still? National innovative productivity among 'follower' countries, 1978-1999. Research Policy, 33(9), 1329-1354. https://doi.org/10.1016/j.respol.2004.09.006

Furman, J. L., Porter, M. E., \& Stern, S. (2002). The determinants of national innovative capacity. Research policy, 31(6), 899-933. https://doi.org/10.1016/S0048-7333(01)00152-4

Ghazal, R., \& Zulkhibri, M. (2015). Determinants of innovation outputs in developing countries: Evidence from panel data negative binomial approach. Journal of economic studies, 42(2), 237-260. https://doi.org/10.1108/JES-01-2013-0016

Gong, G., \& Keller, W. (2003). Convergence and polarization in global income levels: A review of recent results on the role of international technology diffusion. Research Policy, 32(6), 1055-1079. https://doi.org/10.1016/S00487333(02)00136-1

Gotz, M. (2016). Policies Towards the OFDI and IFDI in the European Union after the 2008+ Crisis. Entrepreneurial Business and Economics Review, 4(2), 93-103. https://doi.org/10.15678/EBER.2016.040208

Halkos, G., \& Skouloudis, A. (2018). Corporate social responsibility and innovative capacity: Intersection in a macro-level perspective. Journal of Cleaner Production, 182, 291-300. https://doi.org/10.1016/j.jclepro.2018.02.022

Hipp, C., Grupp, H. (2005). Innovation in the service sector: the demand for service specific innovation measurement concepts and typologies, Research Policy, 34, pp. 517-535. https://doi.org/10.1016/j.respol.2005.03.002

Hu, M. C., \& Mathews, J. A. (2005). National innovative capacity in East Asia. Research Policy, 34(9), 1322-1349. https://doi.org/10.1016/j.respol.2005.04.009

Hu, M. C., \& Mathews, J. A. (2008). China's national innovative capacity. Research Policy, 37(9), 1465-1479. https://doi.org/10.1016/j.respol.2008.07.003

Huang, H. C., Shih, H. Y., \& Wu, Y. C. (2010, July). Constructing national innovative capacity in globalization: The network autocorrelation perspective. In Technology Management for Global Economic Growth (PICMET), 2010 Proceedings of PICMET'10: (pp. 1-12). IEEE.

Yu, L., \& Jianzhong, X. (2011, August). Research on regional technological innovative capacity based on the method of time multi-dimension dynamic comprehensive evaluation. In Artificial Intelligence, Management Science and Electronic Commerce (AIMSEC), 2011 2nd International Conference on(pp. 3275-3279). IEEE.

Kasa, R. (2015). Approximating innovation potential with neurofuzzy robust model. Investigaciones Europeas de Dirección y Economía de la Empresa, 21(1), 35-46. https://doi.org/10.1016/j.iedee.2014.02.001

Litsareva, E. (2017). Success Factors of Asia-Pacific Fast-Developing Regions' Technological Innovation Development and Economic Growth. International Journal of Innovation Studies, 1(1), 72-88. https://doi.org/10.37 24/SP.J.1440.101006

Liu, X., \& White, S. (2001). Comparing innovation systems: A framework and application to China's transitional context. Research Policy, 30(7), 1091-1114. https://doi.org/10.1016/S0048-7333(00)00132-3

Makkonen, T., \& Inkinen, T. (2013). Innovative capacity, educational attainment and economic development in the European Union: Causal relations and geographical variations. European Planning Studies, 21(12), $1958-1976$. https://doi.org/10.1080/09654313.2012.722968

Pereira, C. S., \& Romero, F. C. C. (2013). Non-technological innovation: current issues and perspectives. Independent Journal of Management \& Production, 4(1), 360-376. https://doi.org/10.14807/ijmp.v4i1.88 
Proksch, D., Haberstroh, M. M., \& Pinkwart, A. (2017). Increasing the national innovative capacity: Identifying the pathways to success using a comparative method. Technological Forecasting and Social Change, 116, 256-270. https://doi.org/10.1016/j.techfore.2016.10.009

Que, J., \& Zhang, X. (2018). The role of foreign and domestic venture capital in innovation: evidence from China. Accounting \& Finance. https://doi.org/10.1111/acfi.12401

Sandu, S., \& Ciocanel, B. (2014). Impact of R\&D and Innovation on High-tech Export. Procedia Economics and Finance, 15, 80-90. https://doi.org/10.1016/S2212-5671(14)00450-X

Schumpeter, J. A. (1942). Capitalism, socialism, and democracy. New York, London: Harper \& Brothers.

Solow, R. M. (1956). A contribution to the theory of economic growth. The Quarterly Journal of Economics, 70(1), 6594. https://doi.org/10.2307/1884513

Villa, L. S. (1990). Invention, inventive learning, and innovative capacity. Behavioral Science, 35(4), 290-310. https://doi.org/10.1002/bs.3830350404

Trajtenberg, M., Patents as Indicators of Innovation, Cambridge (MA): Harvard University Press., 1990.

Wu, J., Ma, Z., \& Zhuo, S. (2017). Enhancing national innovative capacity: The impact of high-tech international trade and inward foreign direct investment. International Business Review, 26(3), 502-514. https://doi.org/10.10 16/j.ibusrev.2016.11.001

Zang, L., Xiong, F., Lao, X., \& Gao, Y. (2019). Does governance efficiency matter for national innovative capacity? One tale from different countries. Technology Analysis \& Strategic Management, 31(2), 239-252. https://doi.org/10.1080/ 09537325.2018.1493450

Zeng, D. Z. (2017). Measuring the Effectiveness of the Chinese Innovation System: A Global Value Chain Approach. International Journal of Innovation Studies, 1(1), 57-71. https://doi.org/10.3724/SP.J.1440.101005

Zhang, L. (2017). The knowledge spillover effects of FDI on the productivity and efficiency of research activities in China. China economic review, 42, 1-14. https://doi.org/10.1016/j.chieco.2016.11.001

Zhao, Y., Wang, C., \& Zhou, R. (2010). Study on high-tech industry's innovative capacity of East China. In E-Business and E-Government (ICEE), 2010 International Conference on (pp. 1242-1245). IEEE. https://doi.org/10.1109/ ICEE.2010.318

The article has been reviewed.

Received in February 2019; accepted in June 2019. 